\title{
The Development of Public Relations and E-Book Protocol Based on Active Learning Approach to Improve Learning Motivation and Outcome of Vocational Middle School Students
}

\author{
Umar Yeni Suyanto $^{1}$, Asri Laksmi Riani ${ }^{1}$, Tri Murwaningsih ${ }^{1}$ \\ ${ }^{1}$ Master's Degree Program in Economics Education, Sebelas Maret University, Surakarta, Indonesia \\ Email : umarsuyanto@gmail.com
}

\begin{abstract}
The objective of research was to develop E-book media based on active learning approach that can be accessed offline through Windows or Android Smartphone, to improve the students' learning motivation and outcome in Public Relations and Protocols learning in Vocational Middle Schools (thereafter called SMK) in Lamongan City. The idea of research is based on the fact in the field showing no comprehensive Public relations and Protocol module that can support learning and improve the quality of learning in Vocational Middle School (SMK). The method employed in this research was Hanafin and Peck's Research and Development model applying E-book to Vocational Middle School (SMK) students, particularly in Public Relations and Protocol learning. This research and development was organized in three stages: preliminary study, development, and trial. This article served as the form of idea expansion in dealing with the problem occurring. The result of preliminary study was the development of Public Relations and Protocols E-book media in the form of flow and E-book media design based on active learning approach that is effective and efficient to improve the students' learning motivation and outcome. The design organized contains the measures of developing E-book involving material collection, storyboard development, survey, media development, and media application. In this research, E-book development contains eight learning methods (Jigsaw, Think pair and share, Mind mapping, Numbered heads together, Student facilitator and explaining, Talking stick, Group investigation and STAD) with Active Learning; it is a new innovation expected to improve the students' learning effectiveness. Using those learning methods, the learning design will be more creative, innovative, and comprehensive. The measures of developing E-book media including field study, planning, modeling, construction and application. Technique of analyzing data used was qualitative analysis.
\end{abstract}

\section{Keywords: E-book; Active Learning; Public Relations and Protocols}

\section{INTRODUCTION}

Education plays a very strategic role in improving the quality of human resource and in the attempt of realizing Indonesian nation's ideal in realizing public welfare and intellectualizing the nation life. Indonesian education develops very dynamically so that all aspects and system within it always change along with time development. In this new era, the role of technology is very vital in education development in 
Indonesia. The swift technology globalization current requires every element of education to be technology-literate in order to be competitive. Many education elements are affected by technology development current including education instruments such as learning media, learning module, learning reference, learning module, and learning curriculum. As technology develops, learning module can be integrate printed and computer technologies into learning activity.

It is suggested that E-book can help students through independent learning system and exploring the students' understanding on the material the teacher delivers in learning process [4]. It is also argued that the use of E-book can improve literacy in the students [18]. It is supported by technology use as the learning media [7, 11]. It is stated that the application of active learning can encourage the students to be more active in learning process because the competition circumstance created in the learning process makes the learning circumstance more attractive and motivating the students. Considering the result of research, it can be concluded that the application of electronic media can improve the students' interestedness in the material studied. In addition, the application of active learning can also improve the students' motivation and creativity. Therefore, the combination between electronic media through E-book and the application of active learning in this research is expected to achieve the learning objective more effectively by improving the students' learning motivation and learning outcome.

The material developed in this E-book is the enrichment. The students can increase insight by means of studying the material presented in a more practical Ebook. It will be consistent with the graduate output in Public Relations and Protocols learning in the form of students having responsible character, communication soft skill, leadership ability and able of applying office administrative functions in work realm.

This development of E-book prototype is expected to be student-centered. The competency is emphasized on practice mastery through a visual communication concept in digital media. This research and development focuses on the presentation of independent learning materials, E-book based on active learning. The content of learning applied active learning approach making the students participating in learning process more actively. In active learning, the students will be involved in many learning stages. The learning with active learning refers to a student learning process in various ways/active strategies. Through active strategy, the students are expected to understand and to absorb the material studied, and to obtain maximum learning outcome. Joyful circumstance and creative and innovative learning activity will improve the students' learning motivation.

Data of survey obtained explains the proportion of students that should take remedial test in Public Relations and Protocols subject in the $11^{\text {th }}$ grade of SMK in Lamongan City is as follows: $66.66 \%$ in SMK Negeri 1 Lamongan, $56.66 \%$ in SMK Muhammadiyah 1 Lamongan, and $46.77 \%$ in SMK NU Lamongan. On average, $56.69 \%$ of SMK students in Office Administration major should take remedial test in order to obtain score consistent with the minimum learning passing $(\mathrm{KBM})$. 


\section{LITERATURE REVIEW}

\section{Definition of Learning Module}

It is stated that module is one of teaching materials containing a set of learning experience planned and designed to enable the students to achieve specific competency [5]. Module is a teaching material organized systematically and attractively involving material content, method, and evaluation that can be used independently to achieve the intended competency. Meanwhile, module is defined as a book containing at least all basic components of teaching material aiming to enable the students to learn independently without or with teachers' guidance [13]. A module should represent basic competency to be achieved by students thereby enabling the students with high learning ability to achieve basic competency more quickly than other students. The presentation of module employs good language, attractive appearance and is equipped with illustration.

\section{Definition of E-book}

E-book or digital book is a publication consisting of text, audio, and visual components, and published in digital form that can be read in computer or other electronic appliances. Electronic book is defined as a hardware and software system that can present information in much text to the users and enable the users to explore information within it [2 Pattern. It is stated that "Electronic publication is always attractive to the readers because it is mobile in nature and has dynamic feature [12]. E-book as one of electronic publications in the society or user has attracted attention and has been acceptable to the readers as the users. Meanwhile, E-book is stated offers supplementary media to the students, teacher, and school that can support and improve the learning process $[6,26$ 17]. In this case, the E-book use is limited to students. The use of E-books as textbook in the classroom is a new paradigm particularly in developing countries.

It is argued that the use of book can improve quality, function, and help students and teachers in teaching-learning process $[10,13]$. The application of e-learning can improve the students' understanding on the material taught; in addition the quality of learning can also be improved [15-16]. This fact shows that collaboration between learning reference use and technology can create effectiveness and efficiency in learning.

\section{Active learning Approach}

Active Learning is intended to optimize the use of all potencies the students have, so that all students can achieve the satisfactory learning outcome corresponding to personal characteristics they have [22,25]. In addition, active learning is also intended to maintain the students' attention or to keep the students focusing their attention to the learning process. The assumption of active learning states that students should process information actively to achieve the meaningful learning [13, 21]. The active cognitive process involves selecting relevant information from words and picture. Active learning approach is the one in learning 
system management through active learning methods toward the independent learning. This independent learning ability is the end objective of active learning.

Melvin modifies and expands the statement above into what is called active learning: I forget what I heard, I remember a little of what I heard and saw, I begin to understand what I heard, saw and questioned or discussed with others, from what I heard, saw, discussed, and applied, I acquire knowledge and skill, I teach other what I master [23]. To learn something well, we should hear, see, and discuss it with others. In addition, the students should work on it, meaning representing something in their own way, showing the example, trying to practice skill, and working on the assignment requiring the knowledge obtained. The application of active learning can optimize the students' competency during undertaking practical work [18-19]. This learning model is applied appropriately to vocational education focusing more on the students' skill.

\section{METHOD}

This research was conducted in Vocational Middle Schools (SMKs) in Lamongan City: SMK N 1 Lamongan, SMK NU Lamongan and SMK Muhammadiyah 1 Lamongan. This study was research and development. "Research and Development $(\mathrm{R} \& \mathrm{D})$ is a research method used to develop and to validate products used in learning education" [24]. Developing E-book learning media using adobe flash professional technology based on active learning approach to improve the students' learning outcome and motivation. A learning media developed using adobe flash professional based on active learning was expected to be acceptable to teachers and students. E-book learning media utilizing active learning was the one with the following criteria: can be used easily and can improve the learning effectively and efficiently.

This preliminary study was conducted in Vocational Middle Schools (SMKs) in Lamongan City. The data consisted of primary and secondary data deriving from informant, document, place, and event, collected using interview, observation, and content analysis method. Interview was conducted with teachers and students of SMKs in Lamongan city. This research employed interview guide, observation sheet, questionnaire, and test as the method of collecting data. Techniques of analyzing data used were descriptive narrative one on need data analysis, statistic descriptive on the data of research questionnaire result and effectiveness test including: question item validity test, reliability test, difficulty test, and variance test. Development model to which this research referred was Hannafin and Peck's development design. Hanafin and Peck's model is one of many product-oriented learning designs. Product-oriented model is the learning design model intended to produce a product, usually learning media [1]. The product to be yielded in this research is Public Relations and Protocol E-book based on Active Learning approach.

\section{DISCUSSION}

In this research and development, the author develops E-book media combined with a variety of learning types with active learning approach, that will be adjusted with material characteristics, learning objective and student condition. Through this combination, this E-book can inspire the teachers in applying active learning in the 
class. In this E-book development, the teachers serve to help the students achieve the learning objective in the 2013 curriculum that is very important, in which teachers serve not only as information source but also as learning friends, guide, and inspirer in the learning process.

This Public Relations and Protocols E-book media development applies 8 learning method based on active learning approach: 1) Jigsaw will be applied to Public Relations Definition, Public Relations Concept, Public Relations Development History and Public Relations Characteristic material, 2) Think pair and share will be applied to Public Relations Objectives, Public Relations Function, Public Relations Role and Public Relations Work Procedure material, 3) Mind mapping will be applied to Public Relations Duty in Organization, Public Relations Media, and Public Relations Types material, 4) Numbered Heads Together will be applied to Public Relations Profile (Vision and Mission), Public Relations Ethical code, and Public Relations Position Material, 5) Student facilitator and explaining will be applied to internal Public Relations material; (with employees and stockholder/company owner), 7) Group Investigation will be applied to external Public Relations material; (Relation to community, relation to customers and relation to mass media and press), and 8) STAD will be applied to Relation to Government, Internal Public Relations and stockholder relations material. According to ${ }^{[23]}$ the selection of learning model to be used by a teacher is determined by the characteristics of learning material to be delivered, and more than that can learning model fulfill the students' learning need and can improve the students' learning ability as optimally as possible. The application of learning method differentiation adjusted with the students' learning need is expected to be the solution in improving the learning effectiveness.

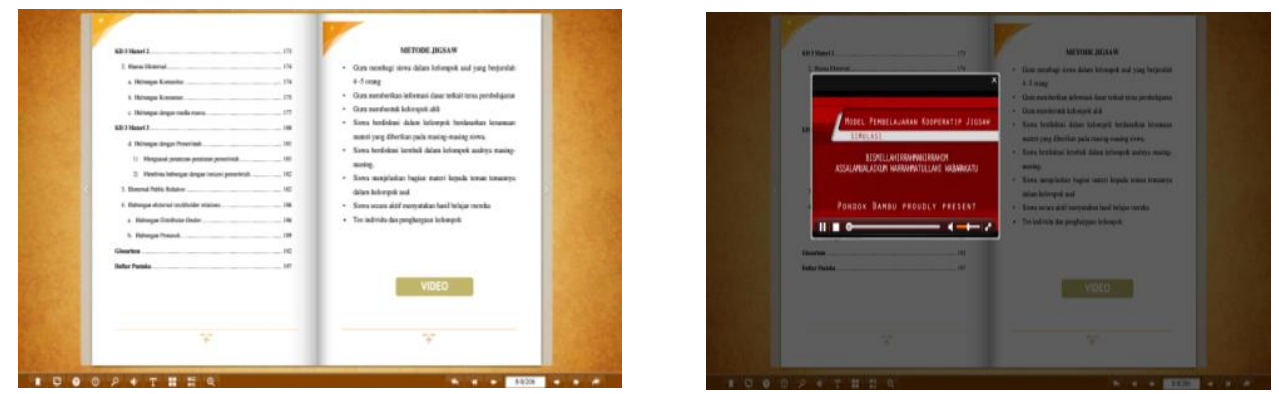

Figure 1. E-book view with guidance of using active learning method
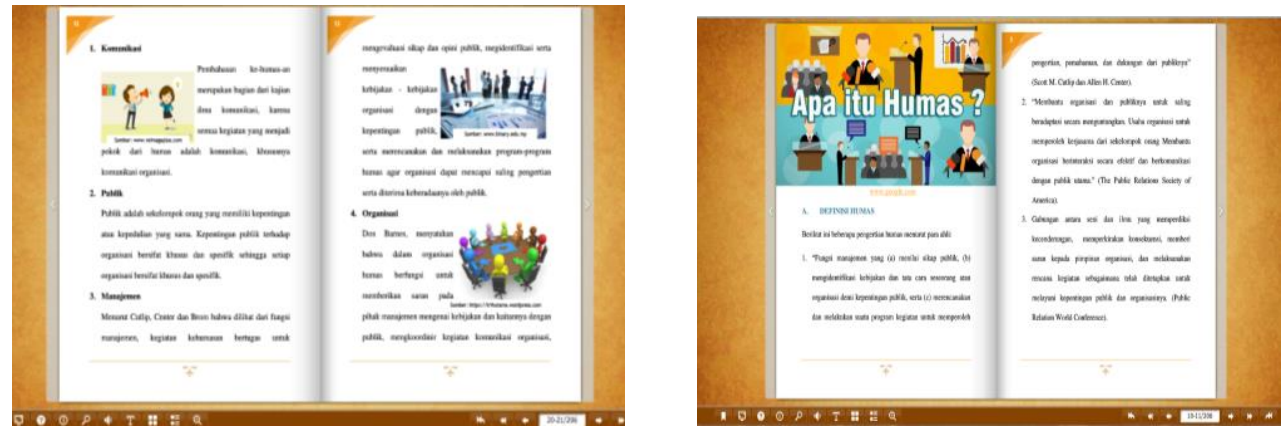

Figure 2. E-book 


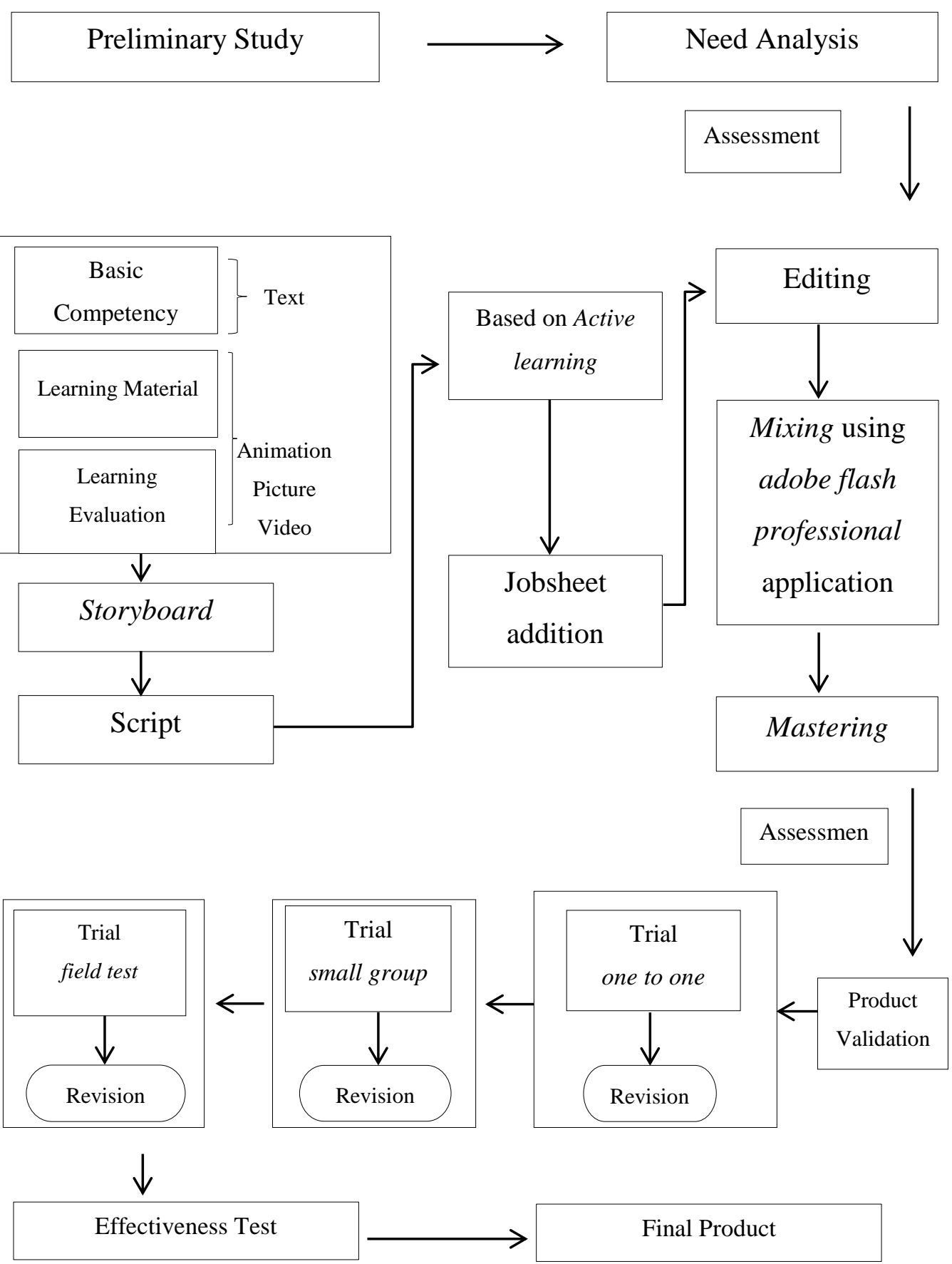

Figure 3. Design of Public Relations and Protocols E-book Development based on active learning approach using Hanafin and Peck model [8]

The development of technology and information over times replaces printed media with digital media. E-book or digital book is a publication consisting of image, text, graphic, curve, audio, animation/video and published in digital form that can be read in computer and other electronic appliances. The development of Active Learning approach-based E-book is the learning approach designed to make the students active in learning process so that they construct information they have 
fluently and have their own learning model and independent learning competency and participate in team. This model is characterized with the use of joyful way or strategy individually or in group to practice and to improve learning motivation and students' curiosity. The teachers' duty should focus themselves on helping the students achieve the learning objective. Prayogi and [20] state that according to constructivism learning theory, teaching is not an activity of transferring knowledge from teacher to students, but an activity of enabling the students to construct their own knowledge.

\section{CONCLUSION}

Public Relations and Protocols learning in Vocational Middle Schools needs understanding and skill in solving problem. For that reason, there should be a learning media that facilitates the students in understanding the Public Relations and Protocols learning. The use of information, and communication technology in education sector is called electronic-based education. Multimedia (text, picture, sound)-based teaching system is an attempt of improving learning quality from the students' understanding and skill in improving learning outcome and learning motivation. The result of preliminary study on E-book media development in this article is the flow or design of media development in the form of Public Relations and Protocols learning E-book based on active learning in the attempt of improving learning outcome and motivation of students. The application of active learning adjusted with material characteristics will help the students absorb and understand the material taught. Through an active learning, all students in the class will be involved in learning process. The design organized contains the measure of developing E-book including preliminary study, material collection, storyboard development, media development, and E-book media application.

\section{REFERENCES}

[1] Afandi dan Badarudin. 2011. Perencanaan Pembelajaran. Bandung: Alfabeta.

[2] Borchers, Jan O. 1999. Electronic Books: Definition, Genre, Interaction Design Pattern, Austria: Linz University.

[3] Chaudhry, Abdus Sattar. 2014. Student Response To E-Books: Study Of Attitude Toward Reading Among Elementary School Children In Kuwait. The Electronic Library Journal. 32 (4): 458-472

[4] Chen, H. Y. \& Jang, S.J. 2013. Exploring The Reasons For Using Electric Books And Technologic Pedagogical And Content Knowledge Of Taiwanese Elementary Mathematics And Science Teachers. Journal TOJET: Educational Technology, 12 (2): 131-141.

[5] Daryanto. 2013. Model Pembelajaran Inovatif. Jogjakarta: Penerbit Gava Media

[6] Embong, A. M., Noor, M. A., Hashim, H. M., Ali, R. M., Shaari, Z. H. 2012. E-Books As Textbooks In The Classroom. Journal Elsevier: Social and Behavioral Sciences, 47: 18021809.

[7] Gusc, Joanna dan van Veen-Dirks, Paula. 2017. Accounting For Sustainability: An Active Learning Assignment. International Journal of Sustainability in Higher Education. 18 (3): 329-340.

[8] Heinich, R., Molenda, C., Russell, J, D., \& Smaldino, S, E. 2002. Intstructional Media and Technologies for Learning: Seventh Edition. Pearson Education: New Jersey. 
[9] Hussin, Husnayati., Bunyarit, Fatimah., Hussein, Ramlah. 2009. Examining Learners' Perspective In Malaysian Institutions Of Higher Learning. Instructional Design And ELearning Journal. 26 (1): 4-19.

[10] Lai, C. 2016. Integrating E-Books Into Science Teaching By Preservice Elementary School Teachers. Journal of Education in Science: Environment and Health (JESEH), 2(1): 57-66.

[11]Lento, Camillo. 2016. Promoting Active Learning In Introductory Financial Accounting Through The Flipped Classroom Design. Journal of Applied Research in Higher Education. 8 (1): $72-87$

[12] Letchumanan, M \& Tarmizi, R. A. 2010. Utilization of E-Book Among University Mathematics Students. Journal Elsevier: Social and Behavioral Sciences. 8: 580-587.

[13] MacVaugh, Jason dan Norton, Mike. 2012. Introducing Sustainability into Business Education Contexts Using Active Learning. International Journal of Sustainability in Higher Education 13 (1): 72-87.

[14] Majid, Abdul. 2012. Perencanaan Pembelajaran Mengembangkan Standar Kompetensi Guru. Bandung: PT Remaja Rosdakarya.

[15] Male, Galamoyo. Pattinson, Colin. 2011. A Socio-Cultural And Technology Perspective Towards Quality E-Learning Applications. Enhancing The Quality Of E-Learning Journal. 28 (5): 331-344

[16] McClelland, Robert . Hawkins, Nick. 2013. Perspectives on the use and development of a broad range of e-books in higher education and their use in supporting virtual learning environments. The Electronic Library. 24 (1): 68-82

[17] Oliveira, Silas Marques. 2012. E-textbooks usage by students at Andrews University A study of attitudes, perceptions, and behaviors. Library Management Journal. 33 (8): 536560

[18] Pierce, Richard. Fox, Jeremy. 2012. Vodcasts And Active-Learning Exercises In A "Flipped Classroom" Model Of A Renal Pharmacotherapy Module. Instructional Design And Assessment Journal. 76 (10): 196-203

[19]Pinto, Maria., Cristina Pouliot., José Antonio Cordón-García. 2014. E-book reading among Spanish university students. The Electronic Library. 32 (4): 473-492.

[20] Prayogi, S. dan Asy'ari, M. 2013. Implementasi Model Problem Based Learning (PBL) Untuk Meningkatkan Hasil Belajar dan Kemampuan Berpikir Kritis Siswa. Jurnal Prisma Sains, 1 (1): 79-87.

[21] Qi Zhou, Xinyu Shao., Ping Jiang Zhongmei Gao., Chaochao Wang Leshi Shu., 2016. An active learning metamodeling approach by sequentially exploiting difference information from variable-fidelity models. Advanced Engineering Informatics. 30: 283-297

[22] Rodriguez, Julia. 2016. A Massively Flipped Class Designing and Implementing Active Learning Information Literacy Instruction for A Large Enrollment Course. Reference Services Review Vol. 44 (1): 4-20.

[23] Silberman, Melvin L. 2006. Active Learning 101 Cara Bealajar Siswa Aktif. Bandung: Nuansa.

[24] Sugiyono. 2011. Metode Penelitian Kuantitatif, Kualitatif dan R\&D. Bandung: Alfabeta.

[25] Victoria. Fratto, Robert Morris. 2011. Enhance Student Learning With Powerpoint Games: Using Twenty Questions To Promote Active Learning In Managerial Accounting. International Journal Of Information And Communication Technology Education. 7 (2): 1320

[26] Wendo , Dickens Rodrigues. Mwanzu , Arnold. 2012. Importance Of E-Books In Improving Access To Scholarly Materials By University Students In Kenya. DESIDOC Journal Of Library \& Information Technology. 33 (8): 1-6 